\title{
The Life of a Sponge in a Sandy Lagoon
}

\author{
MICHA ILAN AND AVIGDOR ABELSON \\ Department of Zoology, Tel Aviv University, Tel Aviv 69978, Israel
}

\begin{abstract}
Infaunal soft-bottom invertebrates benefit from the presence of sediment, but sedimentation is potentially harmful for hard-bottom dwellers. Most sponges live on hard bottom, but on coral reefs in the Red Sea, the species Biemna ehrenbergi (Keller, 1889) is found exclusively in soft-bottom lagoons, usually in the shallowest part. This location is a sink environment, which increases the deposition of particulate organic matter. Most of the sponge body is covered by sediment, but the chimneylike siphons protrude from the sediment surface. The sponge is attached to the buried beach-rock, which reduces the risk of dislodgment during storms. Dye injected above and into the sediment revealed, for the first time, a sponge pumping interstitial water (rich with particles and nutrients) into its aquiferous system. Visual examination of plastic replicas of the aquiferous system and electron microscopical analysis of sponge tissue revealed that the transcellular ostia are mostly located on the buried surface of the sponge. The oscula, however, are located on top of the siphons; their elevated position and their ability to close combine to prevent the filtering system outflow from clogging. The transcellular ostia presumably remain open due to cellular mobility. The sponge maintains a large population of bacteriocytes, which contains bacteria of several different species. Some of these bacteria disintegrate, and may be consumed by the sponge.
\end{abstract}

\section{Introduction}

Infaunal soft-bottom invertebrates benefit from sediment, which provides a dwelling habitat, shelter from predators, and sometimes a source of nutrition (Lopez and Levinton, 1987; Watling, 1991). In contrast, hardbottom dwellers can be harmed by sediment-either as a result of abrasion by moving particles or owing to suf-

Received 15 March 1995; accepted 18 June 1995. focation, shading, and clogging of feeding apparatus by settled particles (e.g., Rogers, 1990).

Sponges, the lowest group of multicellular organisms, are common members of hard-bottom communities (e.g., Schubauer et al., 1990; Soest, 1993). Most sponges are active suspension-feeders that subsist on fine particles such as bacterioplankton and dissolved organic matter (Simpson, 1984). Only a few sponge species inhabit soft-bottom habitats, usually in the deep sea (e.g., Tabachnick, 1991; Werding and Sanchez, 1991), and information on their physiological and morphological adaptation to this environment is scarce. These sponge species may be endangered by two opposing processes in their environment. The first threat is complete burial, resulting from deposition of sediment, which may plug suspension-feeding and respiration channels. The second threat is dislodgment from the substratum, which can occur as a result of the erosive force of moving particles. We may therefore postulate that sponges inhabiting soft-bottom habitats should exhibit specialized adaptations for withstanding effects of cover by sediments and for remaining anchored in place. In addition, they should be able to adjust their feeding mode so that neither burial nor occasional exposure will inhibit their ability to feed.

In the present study, we examined the characteristics of a typical sediment-dwelling sponge species that enable it to survive. In the course of many dives on the reef flat, forereef and deep reef (down to $50 \mathrm{~m}$ ) of Eilat, Red Sea, and the backreef lagoon to search for sediment-specific sponge communities, we observed that one species, Biemna ehrenbergi (Keller, 1889), is confined to the lagoon.

\section{Materials and Methods}

\section{Field observations}

We studied Biemna ehrenbergi in the coral reef lagoon of Eilat, Northern Red Sea $\left(29^{\circ} 30^{\prime} \mathrm{N} ; 3^{\circ} 55^{\prime} \mathrm{E}\right)$. We sur- 


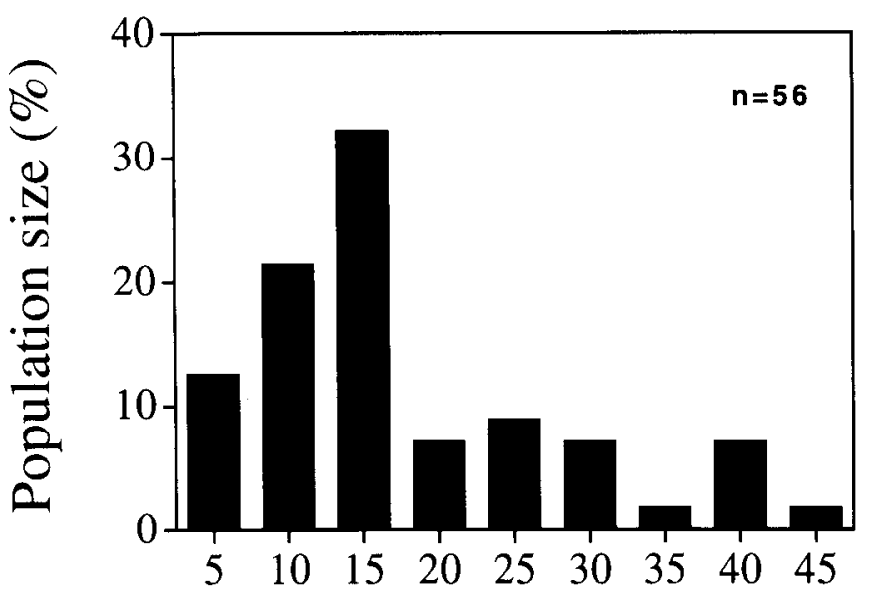

Distance from the shore $(\mathrm{m})$

Figure 1. Spatial distribution of Biemna ehrenbergi in Eilat, Red Sea, along a belt $150 \mathrm{~m}$ long and $40-45 \mathrm{~m}$ wide in the inside lagoon of the coral reef.

veyed a belt $150 \mathrm{~m}$ in length and $40-45 \mathrm{~m}$ in width, recording every sponge within it. The semi-closed lagoon of the Eilat reef encompasses beach-rocks covered with a layer of scdiment of various thickncsscs, patches of coral heads, and small knolls. A third of its water volume is changed each tidal cycle (Lazar, pers. comm.). The effect of tidal currents and the prevailing northern waves is slight, and the flow regime of the lagoon qualifies it as a 'sink', even for fine-sized particles. To determine grain size distribution, cores ( $8 \mathrm{~cm}$ in diameter) of sediment were taken adjacent to sponges, from the surface down to the beachrock. Particles were differentiated by size, dried at $80^{\circ} \mathrm{C}$ for $24 \mathrm{~h}$, and weighed.

\section{Architecture of canal system}

Sponge specimens were perfused in the field with a plastic fluid (Batson's 17 Plastic Replica and Corrosion Kit, Polysciences Inc.) that was injected by syringe into the exhalant openings until it leaked out through the inhalant openings. The fluid was allowed to cure for $12 \mathrm{~h}$, then the specimens were transported to the laboratory and immersed in 10\% sodium hypochlorite for $24 \mathrm{~h}$. The plastic replicas were then rinsed in tap water and observed under a dissecting microscope (protocol modified from Bavestrello et al., 1988).

\section{Ultrastructure analysis}

Sponge samples were fixed $(2.5 \%$ glutaraldehyde buffered in seawater) for at least $24 \mathrm{~h}$. For transmission electron microscopy (TEM), samples were post-fixed with $1 \%$
$\mathrm{OsO}_{4}$, dehydrated, embedded in Epon 812, sectioned, stained with uranyl acetate and lead citrate, and viewed in a JEOL 1200-EX. Ostia (incurrent openings) diameters were measured on photographs taken with a scanning electron microscope.

\section{Canal flow circulation}

Flow direction through the sponge's aquiferous system was recorded by releasing fluorescein dye into the water column near the sponge's "chimneys," or projecting siphons, or by injecting dye into the substratum close to the sponges. When the dye was injected above the sediment, it was difficult to detect currents resulting from the sponge's activity because of background interference. The sponge's siphons were therefore covered with a 1-liter plastic beaker, which was pressed a few centimeters into the sediment. The dye was then injected into the beaker, and its trajectory was followed without the disturbance of external water movements.

\section{Results}

\section{Field observations}

Biemna ehrenbergi sponges were found exclusively within the inner lagoon of the coral reef in Eilat, Red Sea (depth 0.5-1.8 m). Despite numerous dives from the reef flat through the forereef and down to $50 \mathrm{~m}$, no $B$. ehrenbergi specimen was ever found in other areas. A survey conducted along $150 \mathrm{~m}$ of the lagoon (width $40-45 \mathrm{~m}$ ) revealed 56 individuals. Sixty-six percent of the sponges in this belt were concentrated $5-15 \mathrm{~m}$ from the shore (one sponge per $40.5 \mathrm{~m}^{2}$ ), with the rest spread out over the lagoon (one sponge per $145 \mathrm{~m}^{2}$ ) (Fig. 1). Sponge locations within the lagoon typically had particles of various sizes, but $82.5 \%$ of the grains were larger than $500 \mu \mathrm{m}, 13.3 \%$

Table I

Distribution of grain size adjacent to Biemna ehrenbergi sponges (data taken from 5 cores)

\begin{tabular}{lc}
\hline \hline Grain size $(\mu \mathrm{m})$ & $\begin{array}{c}\text { Average percentage of total } \\
\text { grain mass } \pm S D\end{array}$ \\
$X>2000$ & $28.1 \pm 6.4$ \\
$2000>X>1000$ & $27.7 \pm 6.1$ \\
$1000>X>500$ & $29.4 \pm 7.5$ \\
$500>X>350$ & $4.4 \pm 2.4$ \\
$350>X>210$ & $4.0 \pm 2.5$ \\
$210>X>105$ & $4.1 \pm 2.7$ \\
$105>X>74$ & $0.8 \pm 0.5$ \\
$74>X>62$ & $0.3 \pm 0.1$ \\
$62>X>53$ & $0.3 \pm 0.2$ \\
$53>X$ & $1.6 \pm 0.7$ \\
\hline
\end{tabular}



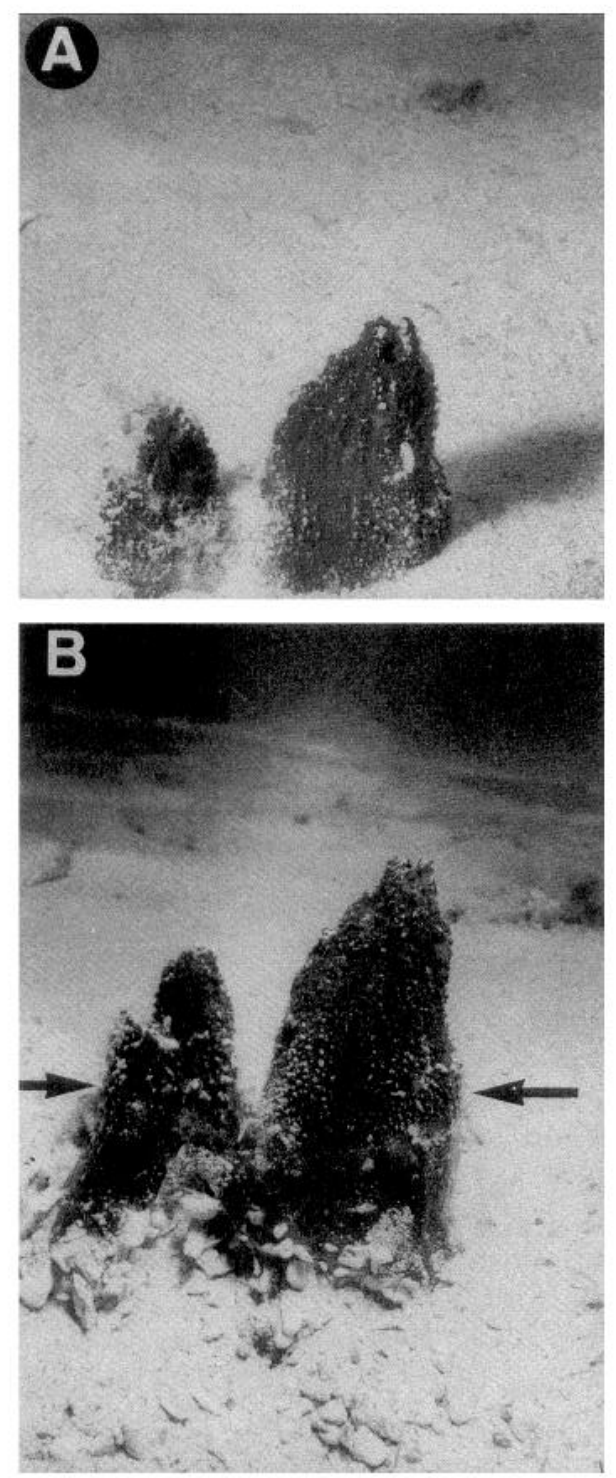

Figure 2. Biemna ehrenbergi in situ. (A) The chimney-like siphons, which are above the sediment surface. (B) The sponge after sediments have been removed. Arrows indicate sediment level.

were of medium size, and less than $2 \%$ were smaller than $74 \mu \mathrm{m}$ (Table I).

We found specimens of $B$. ehrenbergi buried to depths of up to $20 \mathrm{~cm}$, with most of the body covered with sand (Fig. 2A). When the buried part was uncovered it was found to be attached to the beach-rock (Fig. 2B). Moreover, the shape of the buried part resembled a conus with a large base bearing several projections (Fig. 2B). Only these projections - the chimney-shaped siphons-extruded $(1-7 \mathrm{~cm})$ through the sediment (Fig. 2A). Oscula are located at the uppermost part of the siphons.

The sponge is capable of closing its oscula, and thus probably is able to avoid intake of particles during storms.
Observations, using dye injected above and into the sediment $10-15 \mathrm{~cm}$ from the siphons, revealed that most of the water pumped into the sponge came through the pores of the buried surfaces; only a minute amount was taken in by pores on the exposed surface of the siphons. Less than a minute after dye was injected into the sediment, it exited from the oscula in a strong flow; but when injected above the sediment surface, only a small amount of dye emerged from the oscula.

\section{Surface structure and morphology}

Most of the ostia (inhaling openings) are located on the upper surface of the body and are buried in the sediment (Fig. 3b). The exposed siphons are almost devoid of such openings (Fig. 3a). The average size of the oval pores is $9.4 \pm 5.2 \mu \mathrm{m}$, with a range of $4-24.7 \mu \mathrm{m}$ (Fig. $3 b)$. The ostia are transcellular, composed of a single cell (Fig. 3b). The total surface area of the buried parts is extended through processes that protrude from the main central body.

B. ehrenbergi has many small excurrent canals that are accommodated along a central larger canal, leading to the osculum (Fig. 4a). The inhalant canals can be divided into two zones: (a) those of the siphon-like parts of the body, which extend above the substratum surface; and (b) the canals of the body parts that are buried within the sediment. Most of the sponge's soma, which lies beneath the sediment surface, is supported by numerous small incurrent canals and ostia (Figs. 3b, 4b). In contrast, the exposed parts of the body contain few inhalant canals and ostia and a large excurrent canal (Figs. 3a, 4a).

Large quantities of various intracellular bacteria confined within bacteriocytes are a prominent feature in the mesohyl of B. ehrenbergi (Fig. 5a-e). These bacteria appear to be contained in a single large vacuole within the cell (Fig. 5e), or immersed in the cytoplasm without being enclosed by a membrane (Fig. 5a-d). No phototrophic bacteria were found (none of the bacteria appeared to contain photosynthetic membranes). Bacteria within some of the bacteriocytes seemed to disintegrate (Fig. 5b-d), whereas bacteria within adjacent cells appeared intact and divided and grew (Fig. 5b, c).

\section{Discussion}

\section{Sponge distribution}

The distribution of the sediment-buried B. ehrenbergi in Eilat is restricted to a narrow belt at the shallower part of the semi-closed back-reef lagoon in Eilat. The possibility of exposure to a non-oxygenated environment is a major problem for sediment-buried sponges. The oxygen level within the sediment is largely dependent on the tidal and 

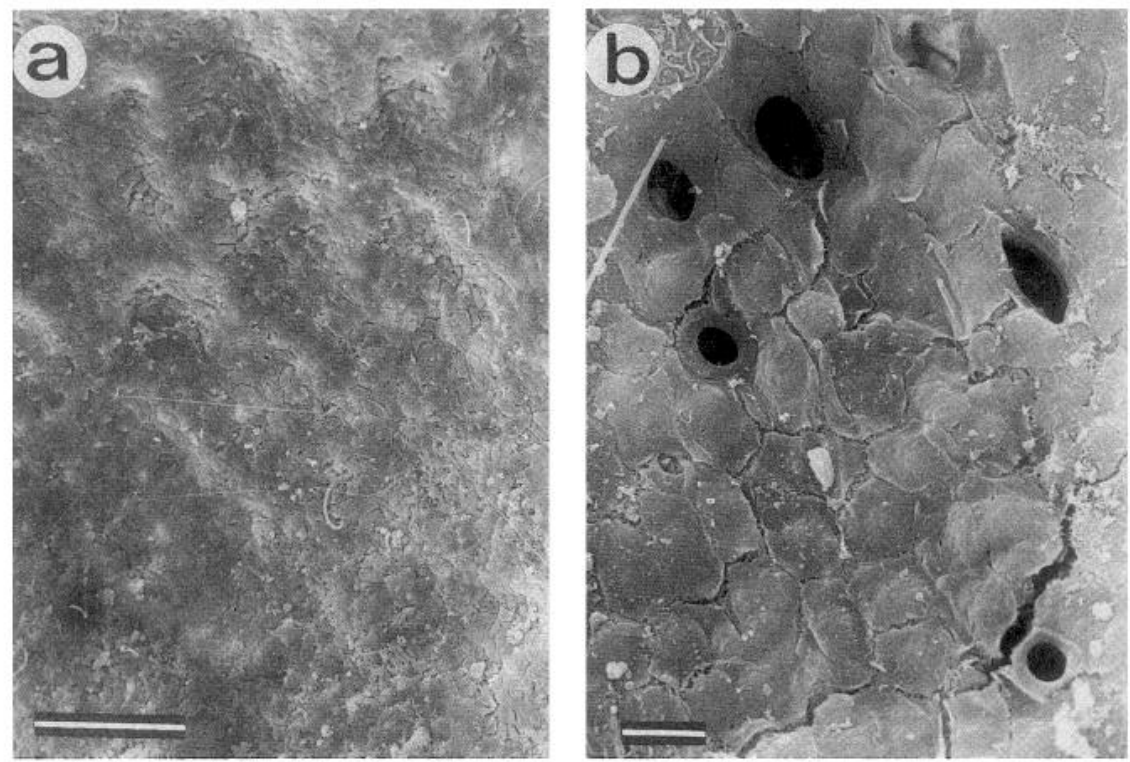

Figure 3. Upper surface architecture of Biemna ehrenbergi. (a) SEM photograph of an area of exposed siphon. Scale bar $=100 \mu \mathrm{m}$. (b) SEM photograph of an area of the exposed upper surface of the buried parts. Scale bar $=10 \mu \mathrm{m}$.

subtidal (wave) pumps (Riedel et al., 1972), as well as on the intensity of the sponge's pumping activity. These two pumps are most effective in shallowest water, at the same depth as $B$. ehrenbergi. We therefore suggest that the sponge's distribution is restricted to an area in which the sediment is mostly oxygenated. Moreover, the large sediment size (small particles are less than $2 \%$ of total grain mass) also contribute to the oxygenation of the sponge's vicinity. A sponge inhabiting a soft-substrate, wave-affected environment is also in danger of being uncovered and dislodged. Because closed lagoons, like many other sheltered habitats, are 'sink environments' in which the rate of sediment deposition is higher than the rate of sediment loss, the sponge's chances of remaining covered are enhanced. B. ehrenbergi also attaches itself to the buried beach-rock, thus providing anchorage and better ability to maintain an upright position following exposure to storms.

\section{Flow and particle path}

The morphology of the canal system of $B$. ehrenbergi, the presence of ostia mostly on the sponge's buried surface, and the observation that the animal can pump in dye injected into the sediment and expel it through the oscula, all provide evidence that this sponge species receives its water supply from the interstitial reservoir. This is a first report of such a pattern of water pumping in sponges. This finding revives and sheds new light on a century-old question: what is the direction of water flow in soft-sed- iment sponges such as Disyringa spp. (Sollas, 1888; Fry and Fry, 1978; Werding and Sanchez, 1991)? On the basis of sponge morphology, it was suggested that Disyringa spp., inhabiting a deep, soft-bottom environment, pumps water in from the interstitial reservoir either through a single large pore (Sollas, 1888) or through several small openings buried in the sediment (Fry and Fry, 1978). Werding and Sanchez (1991) found in laboratory experiments that Oceanapia peltata, with a body morphology similar to that of Disyringa spp., pumps water in from siphons (papillae) projecting above the substrate and discharges it out into the sand. This flow direction is opposite to the one we observed for $B$. ehrenbergi. The fact that sponges are capable of pumping water from the interstitial reservoir, as demonstrated in the present study, suggests that such a direction of water movement may yet be demonstrated in Disyringa spp.

Because water is pumped in from the sediment, buried ostia may be clogged by sediment particles. To avoid this problem, the internal anatomy of the sponges is probably frequently reorganized by continuous cell movements, as shown for other sponges (e.g., Bond, 1992). Such plasticity enables the sponges to open new ostia, overcoming any clogging. Due to cell flexibility, a transcellular opening may be easily moved aside or closed, unlike a system of extracellular openings, which requires coordination between many cells.

The conical shape of the chimney-like siphon of $B$. ehrenbergi gives it a high slenderness ratio (SR) [in which 

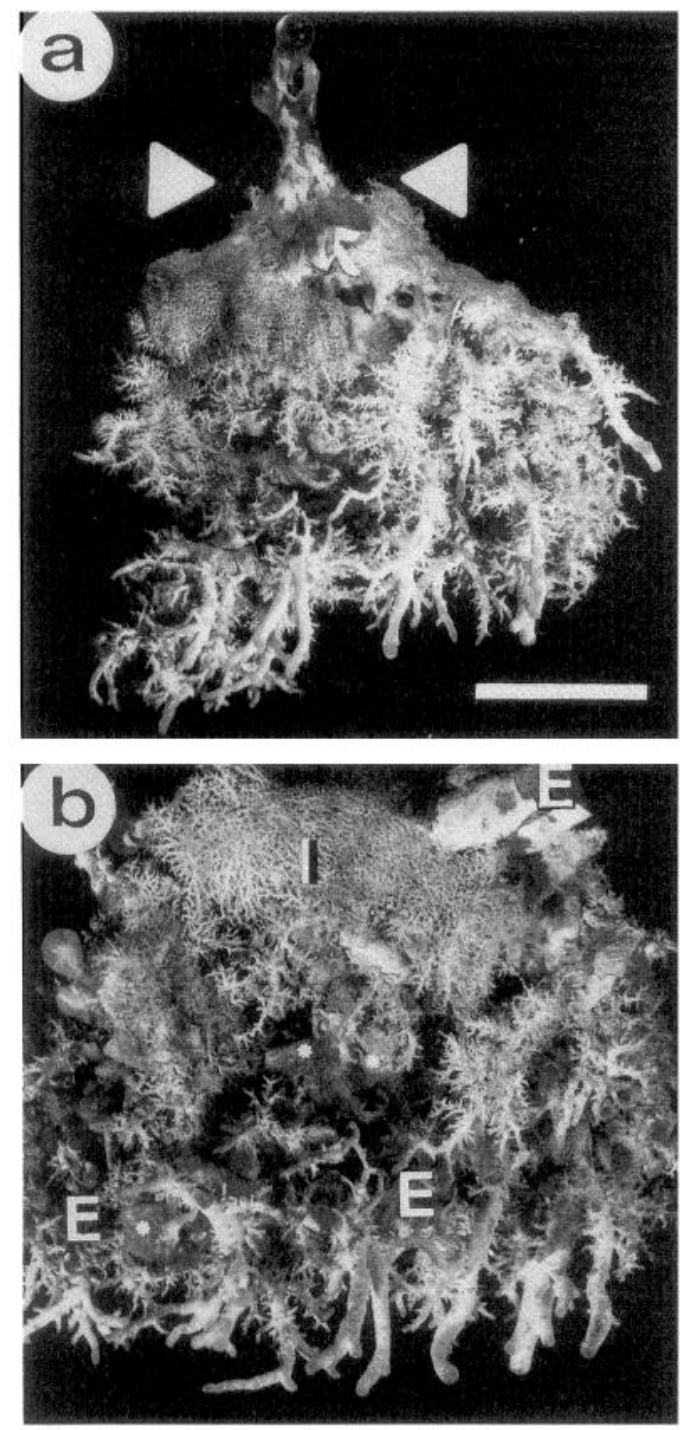

Figure 4. Plastic replica of the aquiferous system of Biemna ehrenbergi (SEM photographs). (a) Gross aquiferous system. Arrowheads indicate the point at the surface of the sediment. Scale bar $=5 \mathrm{~cm}$. (b) A portion of the aquiferous system located underneath the surface: I, high density of small incurrent canals; E, zone of many excurrent canals. The "E" at the top of the picture is positioned on a central excurrent canal that leads to the above-surface osculum; ${ }^{*}$ sand particles entrapped within the sponge.

the ratio of the body height to its lowest width is $>1$ (Abelson et al., 1993)]. This shape prevents ascension of the near-bed flow, and as a consequence reduces the quantities of bedload particles encountering the siphons. In addition to being relatively high above the sediment surface, the oscula remain unclogged because they can close their entrances during unfavorable conditions. This combination of morphology and behavior gives specimens of this species the twofold advantage of being primarily infaunal organisms, yet having exposure to the water column for waste discharge. The separation of sites for intake and discharge of water ensures that no re-filtration of wastewater occurs.

\section{Feeding modes}

$B$. ehrenbergi appears to possess two feeding modes: one that is common to all sponges-filtering small particles out of the water (either above-surface or interstitial water); and a second based on symbiotic intracellular bacteria.

Symbiotic, usually heterotrophic, bacteria have been observed within many sponge species (e.g., Reiswig, 1974; Vacelet and Donadey, 1977; Wilkinson, 1978). Nutrient translocation between phototrophic symbiotic cyanobacteria and their sponge host has been demonstrated (Wilkinson, 1979). In the sclerosponges Ceratoporella nicholsoni and Stromatospongia norae, the numerous symbiotic heterotrophic bacteria are spread extracellularly and are phagocytized in some parts of the sponges (Willenz and Hartman, 1989). In Petrosia ficiformis, as in B. ehrenbergi, symbiotic heterotrophic bacteria are confined intracellularly to bacteriocytes, and no phagocytosis and digestion of these bacteria is observed (Vacelet and Donadey, 1977). The absence of a host membrane around the symbiotic bacteria, as suggested in some of the observed cases, has been considered to indicate a stable association of complex metabolic relationships between the symbiotic partners (Smith, 1979; Saffo, 1990). It may be, however, that even in presence of a vacuole, bacteriocyte cytoplasm had been reduced to a minimum, which would explain its virtual absence in many electron micrographs.

In the present study, transmission electron micrographs provided grounds for suggesting that $B$. ehrenbergi may consume some of its "bacterial farms," while leaving other bacteriocytes intact. Thus there exist, side by side, some bacteriocytes in which the bacteria appear normal and even seem to divide, and others in which the bacteria apparently disintegrate.

In a sink environment (like the reef lagoon), the content of particulate and dissolved organic matter in the sediment is higher than in the water column. For example, dissolved organic carbon is higher in interstitial water than in seawater (Krom and Sholkovitz, 1977), and dissolved free amino acids can be 100 times as concentrated in the interstitial water in the near-surface sediments as they are in the overlaying seawater (Henrichs and Farrington, 1979). We suggest, therefore, that in the lagoon, B. ehrenbergi and its symbiotic intracellular bacteria may benefit from interstitial water rich in organic matter (particulate and dissolved), which the sponge pumps through its buried surface. 

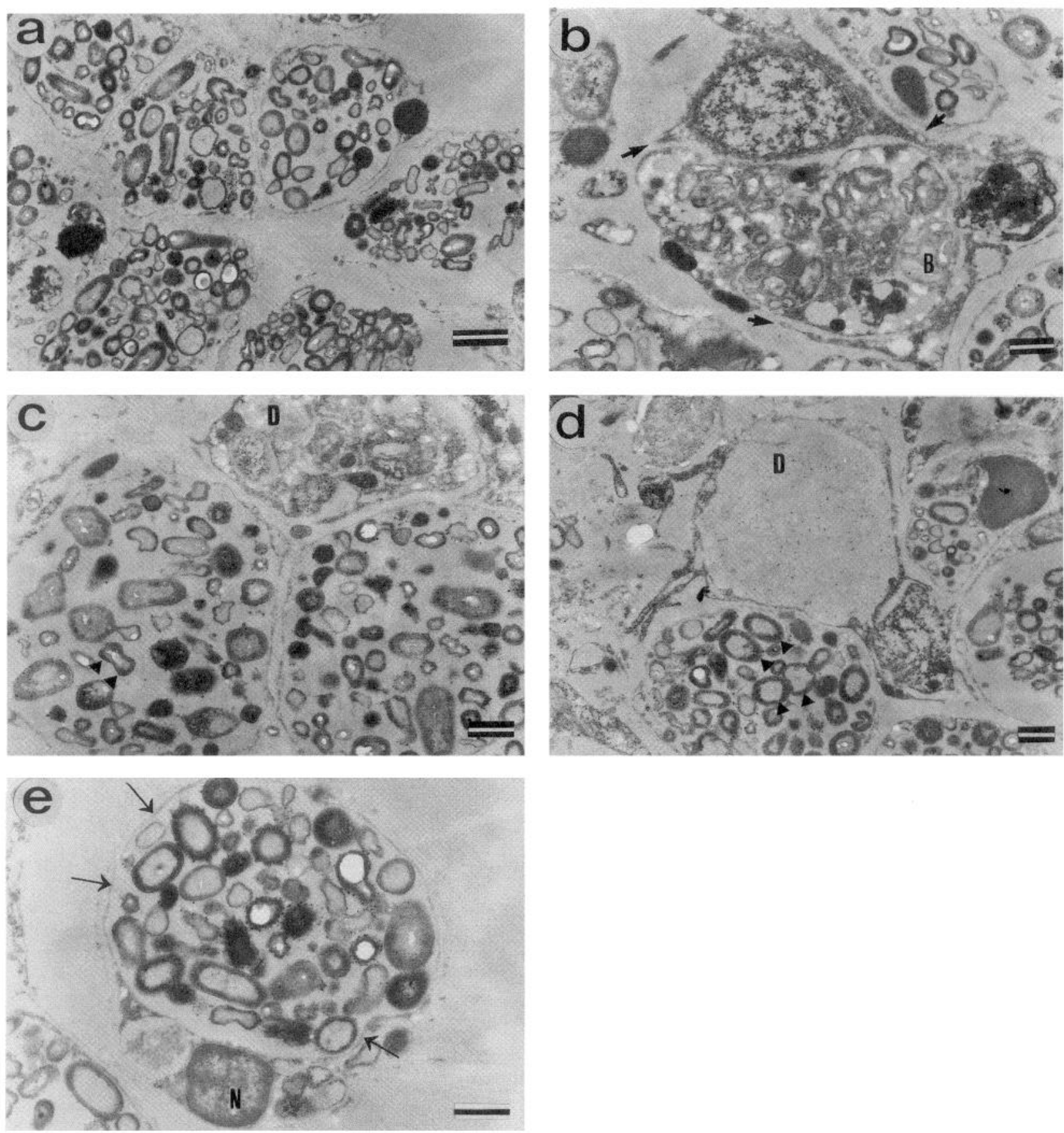

Figure 5. Symbiotic bacteria found in Biemna ehrenbergi (TEM photographs). (a) Bacteriocytes-mesohyl cells that are packed with a large number of intracellular bacteria. Scale bar $=2 \mu \mathrm{m}$. (b) Partially disintegrated bacteria within a bacteriocyte (B). A sponge cell is attached to the bacteriocyte, engulfing it by projections (arrows). Scale bar $=1 \mu \mathrm{m}$. (c) A bacteriocyte in an advanced stage of bacterial disintegration (D), while in two adjacent bacteriocytes the bacterial population seem intact and some bacteria appear to be dividing (arrowheads). Scale bar $=1 \mu \mathrm{m}$. (d) A bacteriocyte with proliferating intact bacteria (arrowheads) adjacent to a cell which resembles a bacteriocyte, but in which no bacteria are seen. Scale bar $=1 \mu \mathrm{m}$. (e) A bacteriocyte with nucleus $(\mathrm{N})$ and cytoplasm, in which the bacteria appear to be enclosed within a vacuole (arrows). Scale bar $=1 \mu \mathrm{m}$. 


\section{Acknowledgments}

We are indebted to Y. Loya for his invaluable support of this study. Y. Delarea helped with the electron microscopy. An extremely thorough review by B. Rinkevich and helpful suggestions from an anonymous reviewer improved the manuscript immensely. We thank the MBL at Eilat for the hospitality and use of lab facilities.

\section{Literature Cited}

Abelson, A., T. Miloh, and Y. Loya. 1993. Flow patterns induced by substrata and body morphologies of benthic organisms, and their roles in determining availability of food particles. Limnol. Oceanogr. 38: $1116-1124$.

Bavestrello, G., B. Burlando, and M. Sara. 1988. The architecture of the canal system of Petrosia ficiformis and Chondrosia reniformis studied by corrosion casts (Porifera, Demospongiae). Zoomorphology 108: $161-166$.

Bond, C. 1992. Continuous cell movements rearrange anatomical structures in intact sponges. J. Exp. Zool. 263: 284-302.

Fry, W. G., and P. D. Fry. 1978. Aspects of the functional anatomy and ecological physiology of Disyringa and some other infaunal tetractinomorph sponges. Coll. Internat. CNRS Biologie des spongiaires. 291: $335-341$.

Henrichs, S. M., and J. W. Farrington. 1979. Amino acids in interstitial waters of marine sediments. Nature 272: 319-322.

Krom, M. D., and E. R. Sholkovitz. 1977. Nature and reaction of dissolved organic matter in the interstitial waters of marine sediments. Geochim. Cosmochim. Acta 41: 1565-1573.

Lopez, G. R., and J. S. Levinton. 1987. Ecology of deposit-feeding animals in marine sediments. Q. Rev. Biol. 62: 235-260.

Reiswig, H. M. 1974. Water transport, respiration and energetics of three tropical marine sponges. J. Exp. Mar. Biol. Ecol. 14: 231249.

Riedel, R. J., H. Huang, and R. Machan. 1972. The subtidal pump: a mechanism of interstitial water exchange by wave action. Mar. Biol. 13: $210-221$.
Rogers, C. R. 1990. Responses of coral reefs and reef organisms to sedimentation. Mar. Ecol. Prog. Ser. 62: 185-202.

Saffo, M. B. 1990. Symbiosis within a symbiosis: intracellular bacteria within the endosymbiotic protist Nephromyces. Mar. Biol. 107: 291296.

Schubauer, J. P., T. P. Burns, and T. H. Richardson. 1990. Population dynamics of five Demospongiae in Jamaica: variation in time and space. Pp. 443-451 in New Perspectives in Sponge Biology, K. Rützler, ed. Smithsonian Institution Press, Washington, DC.

Simpson, T. L. 1984. The Cell Biology of Sponges. Springer-Verlag, New York.

Smith, D. C. 1990. From extracellular to intracellular: the establishment of symbiosis. Proc. R. Soc. Lond. B 204: 115-130.

Sollas, W. J. 1888. Report on the Tetractinellida collected by HMS "Challenger" during the years 1873-1876. Rep. Sci. Res. Voyage "Challenger." 25 i-cixvi: 1-458.

van Soest, R. W. M. 1993. Distribution of sponges on the Mauritanian continental shelf. Hydrobiologia 258: 95-106.

Tabachnick, K. R. 1991. Adaptation of the Hexactinellid sponges to deep-sea life. Pp. 378-386 in Fossil and Recent Sponges, J. Reitner and $\mathrm{H}$. Keupp, eds. Springer-Verlag, Berlin.

Vacelet, J., and C. Donadey. 1977. Electron microscope study of the association between some sponges and bacteria. J. Exp. Mar. Biol. Ecol. 30: 301-314

Watling, L. 1991. The sedimentary milieu and its consequences for resident organisms. Am. Zool. 31: 789-796.

Werding, B., and H. Sanchez. 1991. Life habits and functional morphology of the sediment infaunal sponges Oceanapia oleracea and Oceanapia peltata (Porifera, Haplosclerida). Zoomorphology 110: 203-208.

Wilkinson, C. R. 1978. Microbial associations in sponges. III. Ultrastructure of the in situ associations in coral reef sponges. Mar. Biol. 49: $177-185$.

Wilkinson, C. R. 1979. Nutrient translocation from symbiotic cyanobacteria to coral reef sponges. Pp. 373-380 in Biologie des Spongiaires. C. Lévi and N. Boury-Esnault, eds. Coll. Int. C.N.R.S. 291.

Willenz, P., and W. D. Hartman. 1989. Micromorphology and ultrastructurc of Caribbean sclerosponges. I. Ceratoporella nicholsoni and stromatospongia norae (Ceratoporellidae: Porifera). Mar. Biol. 103: $387-401$. 